\title{
Religion, Society, Theory
}

\section{Citation}

Comaroff, Jean. 2012. "Religion, Society, Theory." Religion and Society: Advances in Research 3 (1) (December 31): 5-34.

\section{Published Version}

doi:10.3167/arrs.2012.030102

\section{Permanent link}

http://nrs.harvard.edu/urn-3:HUL.InstRepos:12876729

\section{Terms of Use}

This article was downloaded from Harvard University's DASH repository, and is made available under the terms and conditions applicable to Open Access Policy Articles, as set forth at http:// nrs.harvard.edu/urn-3:HUL.InstRepos:dash.current.terms-of-use\#OAP

\section{Share Your Story}

The Harvard community has made this article openly available.

Please share how this access benefits you. Submit a story.

Accessibility 


\section{Portrait:}

Religion, Society, Theory

\section{Jean Comaroff}

I grew up in apartheid South Africa, on the sort of colonial frontier that puts established categories at risk. Religion was one of them. Some argue that the separation of the sacred from the secular is a founding principle of liberal modern states (Asad 2003:13). But South Africa was a flagrant exception. There, the line between faith and politics was always tentative, always contested, always palpably porous. Faithbased arguments, there, were central to politics at their most pragmatic, to competing claims of sovereignty and citizenship, to debates about the nature of civilization or the content of school curricula. As a settler-colony, South Africa had long experimented with ways to 'modernize racial domination' (Adam 1971) in the interests of capitalist production, frequently with appeals to theology. After 1948, in contrast with the spirit of a decolonizing world, the country fell under the sway of Afrikaner rulers of overtly Calvinist bent, who set about formalizing a racial division of labor that ensured that black populations, the Children of Ham, remained economically subservient and politically excluded.

The liberal Jewish community in which I was raised included refugees from the Holocaust, and was a distinctly nervous fraction of the dominant class (Bourdieu 1984:186). Its members were white, but not of the herrenvolk, and acutely alive to the perils of racial persecution. Torn between keeping their heads down and voicing moral protest, many found solace in the call of another Zion, in a strong identification with the 
State of Israel that, in 1948, established itself as ethno-nation on the geopolitical world map. But South Africa had also spawned other visions of a Promised Land, ${ }^{1}$ other images of Zion, other millennial aspirations that would color my understanding of religion and society. While I was schooled in a system dubbed Christian National Education (Davies1978), my consciousness was suffused, from early on, by competing political-theologies: by a vibrant brace of liberation movements, for instance, in which evangelical revival confronted - not always peaceably - European socialist thought and New World critiques rooted in the writings of DuBois, Garvey, and Fanon.

Such a world predisposes one, if not to scepticism about any claim to sovereign truth, at least to an acute awareness of the context-dependence of all orders of faith and knowledge. It also fosters distrust of the evolutionary conceits of Western modernity among them, that secularism advances steadily as enchantment declines - and of the idea that religion is everywhere identifiable as that which pertains to the divine or the supernatural. For what can, or cannot, claim to be "religion" (as against heresy, superstition, magic, Satanic rite), and who is or is not authorized to decide, has long been a domain of conflict. And an idiom of establishing hegemony. Early European settlers and evangelists, some of them denounced as heretics at home, often deemed Africans to be devoid of all trace of religion, finding no ready counterpart for their own idea of faith among peoples who had no term for 'religion' or 'belief;' peoples whose word for "spirit" (moya, "breath" in Setswana) albeit an echo of Old Testament usage, remained irretrievably corporeal in conception. Colonial missions labored hard to instil a Protestant ontology - and the mercantile geist it bore - in African consciousness. But 
the dialectic set in motion between European and African religiosity would yield unforeseen mutations, blurring Cartesian divides, queering reigning creeds, calling new revelations into being. In the process, Christianity was Africanized, and Africa Christianized, distilling novel self-awareness on all sides, not least of the ways in which, as Asad (1993:123) has put it, "power create[s] religion;" also, of the ways in which religion creates power - and of how people might act upon that awareness, both as colonizer and colonized.

All this made it plain to me that, while the category of religion was irredeemably relative, in the Euro-modern world at least, a Judeo-Christian definition of the concept was hegemonic - not only in theological orthodoxy and public culture, but in much scholarly analysis as well. In contrast to some anthropologists (e.g. Bloch 2010), these evident facts do not lead me to conclude that no viable theory about religion is possible; that we would do best to free ourselves of the term as analytical category in favor of a putatively more universal one, like "ritual." For me, it is precisely the inescapable embeddedness of religion in particular social-historical formations that is the point fo departure for useful critical investigation.

Of course, it is all a matter of what one takes to be "theory," what one understands as its objects and objectives. For Bloch (2010:5), to be worthy of its name, theory must contribute to "to the general understanding of what kind of animals human beings are." Ritual is more useful than religion in this regard, he argues, because, it can be "described as a specific type of modification of the way human beings communicate"(Bloch 2010:8), this on the basis of universal cognitive qualities of human 
existence. ${ }^{2}$ Religion, by contrast, is not a "natural kind." Its definition remains socially and historically arbitrary. As will be clear, my understanding of theory and its uses in relation to religion, or any other aspect of the social world, is rather different. I am not primarily interested in identifying "natural" kinds, or establishing "general claims about human beings" (Bloch 2010:5) that presume a transcendent vantage. My ethnographic training has reinforced my predisposition to see all categories of human thought and being - including analytical terms like ritual, which I deploy a great deal in my work - as inflected by specific systems of meaning and signification. In this sense, I am interested less in theories of religion, than in theories of religion and society. It is precisely the nature of this relationship and its historically-specific transformations that fascinate me; most specifically, its modern transformations, for those are the ones that our epistemological apparatus engages most effectively, at least in the human sciences (cf. Casanova 2011). What, with twenty-first century hindsight, is the sustained relationship between the Protestant ethic and the nature of capitalism - not to mention the nature of 'modernity' itself? The terms of human knowing and acting are never simply determined, once and for all, by genealogy or context. Neither are they unchanging, or without contradiction and incoherence.

For me, useful social analysis is that which strives, within those limits, to gain reflexive purchase, from a distinct disciplinary location, on particular phenomena of varying scale, generality, and temporality. In my earlier work, for instance, I interrogated the ironic role of evangelical Protestantism as vehicle both of the colonization, and the emancipation of southern African peoples. I did so both as an anthropologist and as a 
person from the South, one especially sensitive to the fact that European religiosity was embedded in a particular hegemonic order of social, textual, and material relations; aware, too, that this ostensibly universal faith was saturated with specific sensibilities and values whose implications were profoundly worldly - and central to imperial efforts to transform African societies and economies whole cloth. The interplay that ensued would significantly refashion the European Christian legacy. ${ }^{3}$ In the process, the ethnocentrism of the latter, and also its ideological role, were often made apparent, raising new sensibilities and prompting anguished debate - among scholars, politicians, churchmen, and a host of new, independent movements - as to who should be deemed Christian. And how the official line should be drawn between church and sect, enlightened belief and primitive mentality. As this suggests, the role of religion was of signal importance in to the modern colonial project tout court, as the necessary "supplement" (Derrida 1976) to secular discourses of reason, civilization, race.

This approach implies a vision of grounded theory in which lived practice including self-conscious theory-making itself - is always seen to exist in a dynamic relation with immediate context and with larger-scale processes of transformation; in which tangible facts, the concrete, cannot be understood without recourse to abstraction, to theory, and vice versa. This also implies reflexive critique: a concern not merely with how social worlds are constituted, but how they might conceivably have been different, and how their present give might give rise to better futures (Horkheimer 1972). This impetus allies me with analytical approaches produced on other authoritarian frontiers - with the kind of immanent critique developed by the Frankfurt 
School, for instance, which probes contradictions, differentiations and paradoxes in the constitution of given worlds, thus to estrange their ruling assumptions, and to envisage other, emancipatory possibilities.

\section{Anthropology and its Spirits of Resistance}

One such critical engagement, for me, was with the self-imposed limitations of the ethnographic tradition in which I was trained at the London School of Economcs in the late 1960's. While the wider world around us was seething with the onset of an already late capitalist, postcolonial moment, British anthropology remained committed, for the most part, to presentist models of small-scale, non-Western polities, still clinging to the possibility of accessing the totality of relations of a society, the essential workings of a culture, in any one place and time (cf. Gupta and Ferguson 1997). To be sure, there were more advantages to this approach than is often acknowledged these days, not least its facilitation of bold theory-making (Comaroff and Comaroff 2012). But the sprawling Tswana-speaking 'homeland' that confronted me as a neophyte fieldworker in the days of high apartheid simply could not be reduced, either ethically or methodologically, to a bounded, self-reproducing "society" or clutch of "villages." Neither could the ever-evolving Zionist churches - whose prophet leaders so captured local imaginations - be readily described as a "traditional" religions. How, then, to acknowledge, in the particularity of the local, forces of "awkward," translocal scale, forces whose historical sociology demanded attention in an age that seemed...postanthropological (Comaroff and Comaroff 2003)?

It was with this task that I wrestled in Body of Power, Spirit of Resistence (1985). 
These overtly syncretic religious movements provided the most sustained, emotionallycompelling focus in the lives of depleted rural communities on the periphery of the South African industrial economy, where they served as its racialized, reserve army of labor. The product both of secession from the colonial missions and of offshoots of late nineteenth-century American revival, these churches, being sites of mimesis and refusal, bore witness to the forces that had shaped this local world. Wielding the creative power of signs, they made the gospel speak of this-worldly redemption, providing a moral lingua franca for a new society of colonized workers and of African nationalist struggle. In seeking to expand my ethnographic gaze to encompass the multi-scalar forces at play in this creative enterprise, I grafted Weber's sense of the Protestant Ethic onto Durkheim's view of the pragmatic power of ritual, and deployed both in a reading of reading of imperialism and race-class formation inspired by Marx. In so doing, I strove to demonstrate something especially evident to those raised in the global South: the role of religion, in the profane business of building, and surviving, markets and empires.

This work drew lively responses, and various strains of critique, some directed at my blatant eclecticism, some uneasy with my readiness to juxtapose "experience-near" ethnography with "inaccessible" theoretical abstraction. Anthropology has always had a strongly empiricist strain, of course, although our founding fathers were more ready to posit bold hypotheses about society and culture than many of their late-modern heirs (Comaroff and Comaroff 2012) - of which more in a moment. A few commentators expressed discomfort with what they saw as an over-readiness to dwell on the social 
and material aspects of religion at the expense of its spiritual dimensions. Some raised this same point in response to Of Revelation and Revolution, the two-volume study I undertook with John Comaroff in the 1990's, which explored the relationship of religion to colonialism by returning to the 'long conversation' between British Nonconformist missionaries and the Southern Tswana peoples. Concerned to pursue the implications of this case for a more general understanding of historical agency - the missionaries were, after all, self-conscious 'agents, not just of God's Kingdom, but also of a 'revolution' of hearts and minds - the study sought also to rethink the concept of culture in relation to the concepts of hegemony, and ideology. And it aimed to do so by way of grounded theory, by training an ethnographic eye on those who seeded a state of colonialism from which the colonial state took root: the churchmen, merchants, and politicians who were the cultural foot-soldiers of empire. This historical anthropology required some experiments in methodology: like assembling an archive that went beyond conventional texts to include objects and archaeological remains, objects that bore witness to the practices that built the substance of a colonial world. Why were trivial commodities so central to the larger spiritual design of God's agents? Why should paper, indigo print, or starched church uniforms have taken on almost magical salience on all sides of the nineteenth century frontier? How did window glass, or the replacement of round dwellings with a square ones, come to index the advance the civilization for its champions? And how did the fetishism of these objects expand imperial commodity markets, and link neophyte proletariats in Africa to workers in Liverpool and Manchester? 
Again, these studies evoked lively commentary, some of it echoing the point that we stressed the worldly, rather than the sacral, dimension of religious phenomena. To which our response has been that this division itself is of more moment to the Cartesian sensibilities of our critics than the bulk of the subjects on whom we focus, although, of course, the latter are hardly devoid of devotional significance. A fact that we endeavored, repeatedly, to convey. Our intention has never been to present a reified analysis of "religion as a cultural system" (Geertz 1973), sans its social and material grounding in the context that gives it life. Besides, it was the enigmatic role of religion in the making of global modernity that was our explicit concern in this project, a choice that neither denies the value of the "religious," narrowly conceived, nor seeks to eclipse its value as worthy of study in itself. Some critics also remain unnerved by our play between scales of analysis, our readiness to identify the presence of large, reifying process - the rationalizing effects of colonial law and literacy, or of proletarianization and the growth of commodity markets - on local African landscapes. Many current anthropologists are strongly committed to the study of local loyalties and systems of knowledge "in their own terms." And, at least in print, to defend the resilience of these systems in the face of global forces besetting "little guys" all over map (Graeber 2002:1223). As Appadurai (1997:115) has noted, this anxiety reveals a fear of a loss of the social intimacy that has long been the ethnographers stock-in-trade; a fear, also, of a loss disciplinary distinctiveness as these same "little guys" are ever more deeply enmeshed in wider worlds.

\section{Zombies and the Violence of Abstraction}


I myself have never been unduly concerned that the anthropological craft was under threat, or that the world to which it bore witness was tragically on the wane. "Primitive" societies, as we all now know, were never the independent isolates they were made to be in much classic ethnography. What is more, the discipline has always drawn on theory from the broader human sciences (from biology to political philosophy, psychoanalysis to linguistics) thus to "scale up," to situate its ethnographic cameos within the wider social, political and economic force-forces and the structural relations that configure them. What remains distinctive about anthropology is its commitment to the role of local meaning and modes of practice in shaping human activity; and its preoccupation with the interplay of subjective value and objective conditions - however complex, labyrinthian, dauntingly 'global' these might be. We respect the fact that our subjects, like we ourselves, seek ways of interpreting the world, ways of engaging the conditions of their being. And, as theorists as varied and Emile Durkheim (1976:277) and Walter Benjamin (1968: 253ff) would have predicted, in the face of "fragmentary realities," the quest for meaningful practice readily finds a mystical, even a messianic, "impetus to action."

The ethnographer's 'ear to the ground' makes her sensitive to these shifts in hermeneutic register - not least, in registers of religious imagination and their intimate entanglement with the challenge of ordinary life. Take the matter of zombies: when John Comaroff and I returned to South Africa after the end of apartheid, we had the promise of new-found freedoms on our minds. The last thing we expected to encounter in the rural communities I knew best was an epidemic anxiety about the living-dead. Yet there 
could be no denying this preoccupation, not only in Tswana communities, but elsewhere in South Africa as well. Far from exotic tales from the backwoods, the presence of zombies was widely discussed in popular culture. Respectable local newspapers carried banner headlines proclaiming "'Zombie' Back From The Dead;"4 defense lawyers in provincial courts argued that their clients had been driven to murder by the zombification of their kin; ${ }^{5}$ and illicit zombie workers were named in formal labor disputes. $^{6}$ In 1995, the Commission of Inquiry into Witchcraft Violence and Ritual Murders (Ralushai et al. 1996:5), appointed by the Northern Province administration to investigate an "epidemic" of occult violence, reported widespread fear of the figure of the zombie - "a person who is believed to have died, but because of the power of a witch, ...is resurrected...[and] works for [him/her]."

While witchcraft has long been integral to Tswana thought, zombies have not. I was struck by the particular features attributed to these specters in vernacular parliance: zombies - the common term here is diphoko, from the Afrikaans spook, or ghost - were spoken about on the street, in private backyards, and in churches. But their mention was almost invariably related to another prevalent concern: the disappearance of work, this amidst radical shifts in the post-apartheid economy under the impact of policies of liberalization. In optimistic policy-speak, the situation was termed "jobless growth." We found the discursive splicing here suggestive: long-standing conceptions of witchcraft, boloi, had come to embrace zombie-making, the brutal reduction of others to instruments of production; to insensate beings stored, it was said, 'like tools' in sheds, 
cupboards, or oil drums of their creators -- the latter usually, if not inevitably, people of conspicuous new wealth, whose source was not readily explicable (cf. Ralushai et al. 1996:50). In a world of flexitime employment, it was even said that some were made into "part-time zombies" (ibid:224-5), whose exhaustion in the morning spoke of involuntary toil on the night shift.

How to make sense of the poetics of this local nightmare, one that seemed to be haunting widening sectors of the national population? If ever there was a figure that typified the sudden rise of joblessness, the mysterious production of wealth without work, and the apparently occult grounding of neoliberal capitalism in local experience, it was the zombie. A creature of "estranged recognition" in perplexing times (Clery 1995:114) s/he was all surplus value, no costly human needs. This kaleidoscopic figure, the ultimate embodiment of flexible, "non-standard," asocial labor was not unprecedented, of course: it comes to us in a range of ethnographic, historical, and literary accounts from Africa and the New World that point both to subtle differences and to noncoincidental similarities. Zombies appear simultaneously translocal and local, simultaneously planetary and - refracted through the shards of vernacular cultural practices - profoundly parochial, just as they appeared, long ago, on the plantations and in the mines of far-flung colonies.

As has been noted before, our concerns here were not, in the first instance, theoretical or conceptual. ${ }^{7}$ We came across the zombie through an empirical conjuncture: it was the force of historical fact, rather than abstract analytical interest, that compelled us to make sense of them in situ. But by what ethnographic means does 
one comprehend human musings on the visceral experience of personal devaluation, both as moral being and as labor power? How to capture a world in which "jobless growth" appears as the mystical capacity of some to thrive on the lifeblood of others? How does one make sense, in other words, of new religious and social movements that accompany radical change in conditions under which people must produce and reproduce their lives and their self-worth? These are not matters that can simply be proven by empirical means, although attention to the texture of local discourse certainly takes one some of the way (cf. Comaroff and Comaroff 1999b). Zombies bespeak intimate community frictions. But they also register the impact on these local worlds of larger forces at once palpable yet opaque, of the violent abstraction that has withdrawn capital - lifeblood - from what once were viable modes of production to invest it elsewhere; away from workers with contracts to cheaper, casualized labor, to machines, to offshore production. When first we lived in the rural, Tswana-speaking north-west, upwards of $80 \%$ of all men spent a sizable proportion of their lives in the migrant economy. By the mid 1990's, that figure had dropped to below 15\%. Grasping the impetus behind such radical transformation requires an act of "inspired guesswork" (Leach 1961:5), both by the organic thinkers that live the effects and by those seeking to understand their situation. What is required is the courage - some would say, the fool-hardiness - to move between the concrete and the concept, poetics and political- economy, to hypothesize about the working of large-scale abstractions so as to posit their relationship to the grounded realities that meet our gaze.

One must be prepared to bear the risks of the "sociological imagination" (Mills 
1959). As with some of my earlier work, the accounts of these transformations - of the culture of neoliberalism and of what John Comaroff and I have termed "occult economies" (1999a) and "millennial capitalism" (2000) - have drawn both rich engagement and robust critique. Much of the latter was concerned, once again, with our readiness to link religion to political economy, local life to large-scale forces (Moore 1999), ethnographic methods to what one pair of critics termed the "meta-narrative of modernity" - phrased by them in such a way as to sound suspiciously like a synonym for "Theory" in the upper case (Englund and Leach 2000). The latter, they claim, "undermine(s)...what is unique in the ethnographic method - its reflexivity, which gives subjects authority in determining the context of their beliefs and practices" (p.225). This objection is at once myopic and irresponsible (Comaroff and Comaroff 2003); it both over-values the role of academic analysis and underrates the impact of structural forces on "local worlds." Local beliefs and practices do not exist in zero-sum relation with macro-forces of modernity. As we, and others, have shown repeatedly, they exist in complex dialectic, a shifting interplay, which itself determines the nature of what is taken to be "local" and/or translocal in the first place (This, pace the critique on the part of some otherwise insightful writers, like Marshall [2009:24-5] who seems carelessly to misread us on this point; cf Geschiere below). To be sure, how and what is "local," how and in what proportion it is situated in worlds beyond itself, is a constant challenge to anthropology. After all, it is world historical processes, like the marginalization of communities I describe above, that threaten the authority of local subjects to determine the context of their beliefs and practices - not the proclivities or activities of social theorists. Certainly, those impacted by the kinds of job loss we witnessed in South Africa 
made their own narrative accounts of this epidemic fully audible. And in an idiom very much their own. In our effort to understand their situation, to locate it in our ever-moreinterdependent world, why would one not draw on the Theory - the "meta-narratives of modernity," if you will - provided by foundational thinkers concerned with the long history of global interdependence; that is, on the likes of Durkeheim, Marx, and Weber.

\section{The Protestant Ethic and the Spirit of Late Capitalism}

In fact, in order to understand the late modern world - including changes within it of the meaning and status of "religion" - my most recent work has returned to precisely the kinds of questions that animated these founding social thinkers. Weber might have been right about many things in this respect, but he could not have been more wrong in his conviction that, as capitalism has matured, the Protestant ethic would cease to be necessary as its ideological impetus. And that enchantment would wither away. Notwithstanding the universal impact of secular rationalization, the line between sacred and secular was never thoroughgoing, save perhaps at the level of ideology, either within European polities or beyond them. In late modern times, that line has become ever more overtly contested, ever more challenged by social and religious movements Christian, Muslim, Jewish, and Hindu alike - that often look less like modern voluntary associations than would-be theocracies: communities at once religious, commercial, and political, governed by divinely inspiration and reformist zeal. Why should this be?,

Elsewhere, John Comaroff and I (2000) have argued that the late twentieth century underwent the kind of radical social, economic, and territorial reorganization akin to that of the Age of Revolution of $1789-1848$, which ushered in the social and 
political architecture of the modern world and erected the conceptual scaffolding of modern social science. The second age of revolution, we suggested, is witnessing another epochal shift in relations among capital, labor, and geo-political organization. The sources of this transformation are complex, of course, linked to the ever more integrated nature of global capital, especially, finance capital; to the salience of ever more abstract, electronically-mediated means of production; to the increasing commodification of culture, services, and affect; to the rise of new kinds of accumulation vested in knowledge, franchises, brands, intellectual property, and so on. These nonproletarian modes of production have dramatically eclipsed the ideological role of labor, in its modern, industrial form, as the recognized basis of generating value both abstract and embodied, (a fact made poignantly manifest by the figure of the zombie). In addition, the sociology of primary production has been reorganized as the quest for cheap, tractable labor has eroded existing bases of industrial manufacture and globalized the division of labor, a process that has been abetted by the growing liberation of corporate enterprise from state regulation. As sites of manufacture and consumption have been dispersed across the earth - America's working class is ever more to be found in Asia, or eastern Europe, for example - connections among these sites and populations have become fragmented and opaque, undermining the very idea of a national economy, in which local interest groups recognize each other as interdependent components of a commonweal (Comaroff and Comaroff 2000).

In the upshot, the spatial articulation of politics and economy has been fundamentally disrupted, and footloose capital has renegotiated the terms of its relation 
to the nation-state, itself ever more corporate. Governments have had to make new kinds of accommodation with business and with translocal market forces, striking novel power-sharing partnerships with private enterprise, both local and foreign. Ruling regimes have tended to outsource key state functions, from customs and excise to prisons and warfare, rendering borders ambiguously both open (to trade, investment, and favored populations) and closed (to immigrants of less desirable quality). Under these conditions, sovereignty is often blurred or overlapping. And ever more intense, disarticulated flows of bodies, goods, and fiscal media link local units in convoluted circuits of exchange that governments are unwilling or unable to regulate. This, in turn, undermines the experience of a cohesive political or moral community, contained by the common space-time of the nation. ${ }^{8}$ The growth of these transnational circuits also disrupts the modern idea of "society," which has presumed the same national-territorial architecture, the same integrity of organization. The disparate horizons mapped by the rapid expansion of deregulated exchange multiply the bases of popular belonging, calling upon people to reconsider the once axiomatic attachments to nation and community. Representation, at once socio-political and semiotic and sociopolitical, is destabilized by these shifts. People loose trust not merely in those who represent their interests, but also in the coinage of public communication itself - and in the face-value of signs. This distrust is heightened, in many places, by the radical devaluation of key media of value, like national currencies. There is a widespread perception, post Bretton Woods, that the real worth of money is inconstant, that the relation between signs and meanings is slippery. Note, in this regard, that the Tea Party movement in the US has 
expressed the desire to return to the gold standard, as if this might stabilize national tender and value tout court. ${ }^{9}$

Revitalized religious movements seem especially capable of finding a foothold on such unsettled terrain (Comaroff 2008; 2009). This raises a key theoretical question for contemporary social analysis: why do faith-based organizations thrive in many contexts where the architecture of modern social institutions, institutions a la Durkheim and Weber, seems to be eroding? Why are these movements so vibrant when prior forms of organization, like labor unions or more orthodox religious denominations, have weakened; where the solid lines between the sacred and profane, the private and public - lines that seem synonymous with liberal modernity - are under attack in many places. I think here of the world-wide evidence of the rapid growth of Pentecostalism and related "renewalist" or "spirit-filled" movements, above all in the global South, where these movements are "reshaping the social, political and economic landscape" 10 by engaging in mainstream politics, business, and civic life with the express aim of putting "God-in-everything," so "anything-can-be-holy." 11 Born-again belief, I stress, is not an autonomic responses to "neoliberal" transformation. Revitalized faith has often run ahead of neoliberalism, bearing the aspirations, the visions of a this-worldly millennium, that prepare the ground for radical, market-oriented reform. This raises an historical Weberian question about the relationship between the "neo-Protestant" Ethic (often linked to a 'prosperity gospel,' with faith in 'Jesus and the market' [Kintz 1997]) and a millennial spirit of capital in our own Age of Transformation. 
What this suggests, once again, is that we inhabit a moment that raises, if in new guise, many of the founding questions of the social sciences, questions first posed by the rise of modern society within the framework of liberal democracy, industrial capitalism, and the nation-state. Now, as older maps are socio-political space are over written by a global division of labor, a planetary economy, and a virtual electronic commons, how do social groups organize themselves and their processes of social and moral reproduction? What undergirds authority now that sovereign forces are blurred, undermined, displaced? What defines human worth as shifts in the nature of work, and in the production of value, suddenly render large sectors of the population irrelevant, incapable of self-sustenance, disposable - as they did with the rise of the modern industrial world, which bred its army of own predatory specters (Thomas 1971)? Are radically different forms of mutuality, of emancipatory politics, made possibile by new communicative media? Or are the latter merely novel vehicles for long-standing social and moral processes? Are new kinds of effervescence evoked by televangelicals and cyber-congregations, when messages can be emailed to the Wailing Wall c/o www.Email-God.org? Or does mystery get lost in the wiring, the graft, the infinite loops of the virtual social network?

Certainly, ours is not the spiritless age that rationalist theorists of modernization predicted. Faith, whatever we make of it, is born-again in late modern times. For Adorno (1981:95) "phantasmagoria comes into being when, under the constraints of its own limitations, modernity's latest products come close to the archaic." In one guise or another, religion remains, remaking itself as the domain in which temporal sovereignty gives way, inevitably, to an authority of a radically different kind. Destined ever to "run 
ahead" of prevailing forms of human reason, as Durkheim foresaw, faith exists in mutually constitutive relation with society. It is its necessary other, as it were, whether to legitimize established arrangements or to wield its revelatory force, its otherworldly legitimacy, in order to 'speak truth to power.' For the social scientist at least, our concerns must lie precisely in this dialectical relationship: in the endless, reciprocal interplay of religion and society, in its restless historical permutations.

Bibliography:

Adam, Heribert

1971

Modernizing Racial Domination: South

Africa's political dynamics. Berkeley: University of California Press.

Adorno, Theodor W.

1981 In Search of Wagner. Translated by R. Livingstone. London: New Left Books.

Appadurai, Arjun

1997

"Discussion: Fieldwork in the era of globalization." In Sandra Bamford and Joel Robbins (eds) Fieldwork in the Era of Globalization. Special issue of Anthropology and Humanism 22(1):115-8.

Asad, Talal

1993 Genealogies of Religion: Discipline and reasons of power in Christianity and Islam. Baltimore,MD.: Johns Hopkins University Press.

2003 Formations of the Secular: Christianity, Islam, modernity. Stanford: Stanford University Press.

Benjamin, Walter

1968 "Theses on the Philosophy of History." In Illuminations, edited by Hannah Arendt, translated by Harry Zohn. New York: Harcourt, Brace \& World, 253-264.

Bloch, Maurice

2008 "Why Religion is Nothing Special but is Central." Philosophical Transactions of the Royal Society B 363:2055-61. 
Bourdieu, Pierre

1984 Distinction: A Social Critique of the Judgement of Taste. Translated by

Richard Nice. Cambridge, MA: Harvard University Press.

Casanova, José

2011

"Portrait: From Modernization, to Secularization, to Globalization." Religion and Society 2:25-36.

Clery, E. J.

1995

The Rise of Supernatural Fiction, 1762-1800. Cambridge: Cambridge University Press.

Comaroff, Jean

1985 Body of Power, Spirit of Resistance: The culture and history of a South African people. Chicago: University of Chicago Press.

2008 "Uncool Passion: Nietzsche meets the Pentecostals." Max Weber Lecture 10/08. Badia Fiesolana: European University Institute.

2009 "The Politics of Conviction: Faith on the neoliberal frontier." Social Analysis 53(1):17-38.

Comaroff, Jean and Comaroff, John

1999a "Occult Economies and the Violence of Abstraction: Notes from the South African postcolony." American Ethnologist 26(3):279-301.

1999b "Second Thoughts: a Response to Sally Falk Moore." American Ethnologist 26(3):307-309.

1999c "Alien-nation: Zombies, immigrants, and millennial capitalism." Codesria Bulletin, 3/4:17-28. Reprinted in Brian Axel (ed) Historical Anthropology and its Futures. Durham, N.C.: Duke University Press, 2002.

2000 "Millennial Capitalism: First thoughts on a second coming." In J. Comaroff and J.L. Comaroff (eds) Millennial Capitalism and the Culture of Neoliberalism. Durham, N.C.: Duke University Press, 1-56.

2003 "Ethnography on an Awkward Scale: Postcolonial anthropology and the violence of abstraction." Ethnography 4(2), 291-324.

Comaroff, John and Comaroff, Jean 
2012 "Foreword: Thinking Anthropologically, About British Anthropology." In Richard Fardon, John Gledhill, Olivia Harris, Trevor Marchand, Mark Nuttall, Chris Shore, Veronica Strang, and Richard Wilson (eds), Sage Handbook of Social Anthropology. London: Sage, with the Association of Social Anthropologists of the United Kingdom and Commonwealth (forthcoming).

Davies, John Leighton

$1978 \quad$ Christian Nation Education in South Africa: A study in the influence of Calvinism and nationalism on educational policy, Vol. 1. Madison, WI: University of Wisconsin Press.

Derrida, Jacques

1976 Of Grammatology. Translated by Gayatri Chakravorty Spivak. Baltimore: The Johns Hopkins University Press.

Durkheim, Emile

1976 [1912] The Elementary Forms of the Religious Life. Guildford, Surrey: Allen and Unwin.

Englund, Harri and Leach, James

$2000 \quad$ "Ethnography and the Meta-Narratives of Modernity." Current

Anthropology 41(2):225-48.

Geertz, Clifford

1973 "Religion as a cultural system." In The interpretation of cultures: selected essays. New York: Basic Books, pp.87- 125.

Graeber, David

2002 "The Anthropology of Globalization (with Notes on Neomedievalism, and the End of the Chinese Model of the Nation-State." American Anthropologist 104(4):1222-1227.

Gupta, Akhil and Ferguson, James

1997 'Discipline and Practice: 'The field' as site, method, and location in anthropology." In Akhil Gupta and James Ferguson (eds)

Anthropological Locations: Boundaries and grounds of a field science. Berkeley:University of California Press, 1-46.

Horkheimer, Max

1972

"Traditional and Critical Theory." In Critical Theory: Selected Essays. Trans. Matthew J. O'Connell, et al. New York: Herder and Herder, $188-243$ 
Kintz, Linda

1997

Between Jesus and the Market: The emotions that matter in right wing America. Durham, N.C.: Duke University Press.

Leach Edmund R.

1961 Rethinking Anthropology. London: Athlone Press.

1964 Political Systems of Highland Burma: a study of Kachin social structures London: G.Bell.

Marshall, Ruth

2009 Political Spiritualities: The Pentecostal Revolution in Nigeria. Chicago: University of Chicago Press.

Mills, C. Wright

1959

The Sociological Imagination. London: Oxford University Press.

Moore, Sally Falk

1999 "Reflections on the Comaroff Lecture." American Ethnologist 26(2): 304-306.

Ralushai, N.V., M.G. Masingi, D.M.M. Madiba, et al. 1996. Report of the Commission of Inquiry into Witchcraft Violence and Ritual Murders in the Northern Province of the Republic of South Africa (To: His Excellency the Honorable Member of the Executive Council for Safety and Security, Northern Province). No publisher given.

Thomas, Keith

1971 Religion and the Decline of Magic: Studies in popular beliefs in sixteenth and seventeenth-century England. London: Weidenfelt and Nicolson

Turner, Victor W.

1967 A Forest of Symbols: aspects of Ndembu ritual. Ithaca: Cornell University Press. 